This item was submitted to Loughborough's Research Repository by the author.

Items in Figshare are protected by copyright, with all rights reserved, unless otherwise indicated.

\title{
Does culture impact private label performance
}

PLEASE CITE THE PUBLISHED VERSION

https://doi.org/10.1108/IMR-02-2016-0038

PUBLISHER

(c) Emerald

VERSION

AM (Accepted Manuscript)

\section{PUBLISHER STATEMENT}

This work is made available according to the conditions of the Creative Commons Attribution-NonCommercialNoDerivatives 4.0 International (CC BY-NC-ND 4.0) licence. Full details of this licence are available at: https://creativecommons.org/licenses/by-nc-nd/4.0/

\section{LICENCE}

CC BY-NC-ND 4.0

\section{REPOSITORY RECORD}

Budhathoki, Tribikram, Julien Schmitt, and Nina Michaelidou. 2019. "Does Culture Impact Private Label Performance". figshare. https://hdl.handle.net/2134/24185. 


\section{Does Culture Impact Private Label Performance?}

\section{ABSTRACT}

Purpose - To better understand the disparity of private label performance across countries, the present study investigates the role played by national culture. Two types of impact are considered: a direct influence of cultural dimensions on the performance of private labels in a country and an indirect one where national culture favours the development of modern retailers, which in turn benefits private label performance.

Design/methodology/approach - Using the five dimensions of Hofstede’s model to describe national culture, this paper performs a SEM incremental building model approach using secondary data collected from a sample of 65 countries.

Findings - The results show that individualism (positively) and long-term orientation (negatively) directly impact private label performance. Moreover, four dimensions (individualism, masculinity, power distance and uncertainty avoidance) are shown to have a significant indirect impact on private label performance via the mediation of retail market development, positively for individualism and negatively for the three other dimensions. Practical implications - The findings provide retailers with important insights into the critical decisions of the selection of new markets and adaptation of the private label strategy according to the culture of the country.

Originality/value - This research pioneers by being the first to 1) determine the impact of all the dimensions of the Hofstede cultural model on private label performance, 2) use a very large number of countries to test this impact and 3) study the role of important retail market factors in this phenomenon.

Keywords: Private labels, Culture, Retail market development

Paper type: Research paper 


\section{INTRODUCTION}

Considerable inter-country differences exist in terms of private label performance ${ }^{1}$. Recent surveys report a high penetration of private labels in Western European countries (45\% in Switzerland, 41\% in the UK and 34\% in Germany) but relatively low performance of private labels in Asian markets, with Hong Kong and Singapore having the largest share (8\% and 5\%, respectively) (Nielsen, 2014). This is an important issue for retailers as private labels represent a key aspect of their strategy (Sethuraman and Gielens, 2014): not only do these brands carry the retailer's name and help to build and promote a store brand identity (Gomez and Okazaki, 2009), but they are also owned and managed by the retailer itself, which allows for better control over their own marketing mix and supply chain (Dhar and Hoch, 1997). This issue is particularly strategic in internationalisation processes (Burt et al., 2005): when a retailer relying heavily on private labels has to decide in which new country to set up, one of the fundamental questions to address is whether their private label strategy is likely to succeed and, if not, which adaptations should be performed to maximise the chances of success. Therefore, understanding the reasons for such a disparity in private label performance across countries is a key issue for retailers.

This disparity between countries has mainly been attributed to factors such as the level of concentration of the retail market (Cuneo et al., 2015), the power balance between retailers and manufacturers (Rubio and Yague, 2009) and the marketing efforts of retailers and manufacturers (Steenkamp and Geyskens, 2014). While all these factors are important to explain the difference in terms of private label performance across countries, research has called for a more thorough investigation of the role of national culture in that regard: 'to understand the inter-country differences on own-label brands usage....studies on the effect of national culture on own-labels market share are important' (Hyman et al., 2010, p. 381).

\footnotetext{
${ }^{1}$ Performance is defined in this study as the level of market share reached by private labels.
} 
Therefore a handful of studies have started to investigate the influence of some cultural dimensions on private label performance. For instance, private label performance has been shown to be positively related to individualism (Herstein et al., 2012; Lupton et al., 2010), negatively related to uncertainty avoidance (Erdem et al., 2004) and unfavoured by materialistic and post-modernist cultures (Steenkamp and Geyskens, 2014).

However, these investigations are limited in their scope. First, none of the existing studies examines the respective influence of all the dimensions of a whole cultural model. Most of them solely focus on one cultural dimension (mainly individualism), while the impact of the other dimensions has been overlooked, much to the regret of some researchers (Kirkman et al., 2006). Second, most of these studies compare only a very limited number of countries, typically two or three countries, albeit past research has claimed that this number was not sufficient to isolate the impact of national culture (Cadogan, 2010). Third, many studies do not measure the objective performance of private labels (i.e. actual market share) but rather only individual consumers’ attitudes and preferences that can be different from actual purchases (Jamieson and Bass, 1989). Finally, these studies apprehend the impact of culture on private label performance without taking into account the characteristics of the retail market in which this phenomenon takes place. This is a critical omission, as past studies have shown that private label performance has been influenced by the development of modern retail chains (Bell, 2003; Steenkamp and Dekimpe, 1997), which in turn could be influenced by the cultural environment in which these retailers operate (Goldman et al., 2002). One can therefore assume that culture does not only have a direct impact on private label performance but also an indirect one through retail market development.

The present study aims to overcome all these limitations. To do so, we collect data on 65 countries and empirically test a framework that theorises the impact of cultural dimensions on the performance of private labels. Our model takes into account the five dimensions of the 
Hofstede’s cultural model (Hofstede, 1980; Hofstede et al., 2010), namely power distance, individualism, masculinity, uncertainty avoidance and long-term orientation. Moreover we integrate in our model the variable of retail market development, which we define as the sales per capita of modern retailers, and we study its mediating role in the relationship between culture and private label performance. Finally, we incorporate control variables such as competitive intensity and other important socioeconomic factors such as GDP per capita, government expenditure and income distribution. Structural equation modelling is used to test the model by utilising data from the packaged food category, which was chosen because of the importance of private labels in this market (Lamey et al., 2012). Table 1 provides an overview of our contribution compared to previous research on this topic.

\section{--- INSERT TABLE 1 ABOUT HERE ---}

In accordance with past research, our results show that the direct impact of culture on private label performance is limited to the positive influence of individualism. This certainly explains why this specific dimension has been studied to such a large extent in this context while the others have been neglected or even overlooked. However, interestingly, we find that culture has an important indirect influence on private label performance through the mediation of retail market development with significant impact of four out of five dimensions. Given that the market adaptation of private labels is one of the key issues in international retailing (Dawson and Mukoyama, 2007), this finding has important implications for international retailers: it can guide them to more successfully choose the countries in which they want to install and to adapt their private label strategy to each national market. 


\section{THEORETICAL DEVELOPMENT AND CONCEPTUAL MODEL}

The Impact of Culture on Private Label Performance

Culture is a vague and abstract notion that has been the object of numerous definitions in the social sciences. Essentially, culture is considered to be a set of shared behavioural patterns, beliefs, norms or values (Triandis, 1994) that provide collective keys to a society for people to understand each other (De Mooij, 2011). Past research has gathered strong evidence that these shared norms and values are eventually reflected in people’s consumption decisions (Petersen et al., 2015; Singh, 2006) or shopping practices (Ackerman and Tellis, 2001). Culture has also been shown to influence nearly all facets of firms’ marketing activities in today’s global marketplace, including advertising (De Mooij, 2013), retailing (Bello and Dahringer, 1985) and the management of marketing environments (Doran, 2002). Therefore, there is a strong rationale behind questioning whether the large geographical disparity that exists regarding private label performance is, at least partly, due to culture.

Among the multitude of cultural models proposed in the literature, the three most commonly used are the Schwartz model (Schwartz, 1992), the GLOBE model (House et al., 2004) and the Hofstede model (Hofstede, 1980). The present study adopts the Hofstede model for three main reasons. First, despite numerous criticisms (e.g. Ailon, 2008), this model has empirically proven its validity in various fields of marketing (e.g. Eisend et al., 2016; Yeniyurt and Townsend, 2003). Second, it is the only model for which the cultural dimensions’ values are available for a large number of countries (Smith, 2006). Finally, it corresponds conceptually to the country-level analysis adopted in this study (Soares et al., 2007). On this basis, this study uses the country scores provided by Hofstede's culture model on the following dimensions: power distance, individualism, masculinity, uncertainty avoidance and long-term orientation. The following paragraphs provide theoretical justifications for the direct impact of each Hofstede dimension on private label performance. 
Direct Impact of Power Distance. The concept of power distance is defined as 'the extent to which the less powerful members of organizations and institutions accept and expect that power is distributed unequally' (Hofstede, 2001, p. 19). In high power distance (PD) cultures, people accept a hierarchical order wherein everyone has a place that needs no further justification. On the contrary, people in low PD societies strive for power equalisation (Hofstede, 1984). Previous research argues that the level of PD is reflected in people's consumption behaviour, particularly their choice of brand (De Mooij and Hofstede, 2010; Roth, 1995). Hence, in cultures characterised by high levels of PD, people place more emphasis on brands that reflect "status" as well as their "rightful place” within one’s society (Robinson, 1996). Such brands have been shown to generally be well-known global brands rather than standard private labels (Kim and Zhang, 2011). On this basis, we hypothesise the following:

H1a: There is a direct negative relationship between power distance and private label performance.

Direct Impact of Individualism/Collectivism. Individualism is associated with an emphasis on independence and self-reliance, while collectivism reflects an emphasis on interdependence and belongingness (Lalwani et al., 2006). Previous research indicates that in individualistic cultures, a person's attitudes and behaviour are regulated mostly by individual preferences, whereas in collectivistic societies, attitudes and behaviour are heavily influenced by societal norms (Triandis, 1989). Hence, individuals in collectivist cultures are more sensitive to the concept of "face” (Bolton et al., 2010) and have a higher tendency to purchase products that reflect “status” (Erdem et al., 2006), leading to a higher rejection of private labels. On the contrary, consumers in individualistic countries are more prone to buy lower-status products to maximise other personal interests (e.g. cost saving and convenience), 
which are easily achieved through the purchase of private labels. Past research seems to corroborate this, as private label consumption has been consistently found to be higher in individualistic cultures (De Mooij and Hofstede, 2002; Lupton et al., 2010; Shannon and Mandhachitara, 2005). Based on this stream of literature, the following hypothesis is proposed:

H1b: There is a direct positive relationship between individualism and private label performance.

Direct Impact of Masculinity/Femininity. Masculine cultures tend to form societies where gender roles are clearly distinct: males are expected to be tough, dominant and assertive, while females are supposed to be humble and reserved (Hofstede et al., 2010). Consequently, it has been shown that many decisions, including consumption decisions, are more likely to represent the masculine values of the dominant household member, which generally are ambition, materialism, performance and achievement (De Mooij and Hofstede, 2010). Within a consumption context, it has been shown that individuals from masculine cultures have a higher desire to own more expensive and selective brands, as these brands are more prone to act as cues to indicate social status than generic brands (De Mooij and Hofstede, 2002; Petersen et al., 2015). Additionally, when describing their idea of what a “good life” is, people from masculine cultures mention famous manufacturers’ brand names more frequently than do people from more feminine cultures (Zinkhan and Prenshaw, 1994). Moreover, culturally masculine values such as performance and achievement have been shown to be more linked to manufacturer brands than to private labels, as the former are considered more reliable and durable (De Mooij and Hofstede, 2010). Therefore:

H1c: There is a direct negative relationship between masculinity and private label performance. 
Direct Impact of Uncertainty Avoidance. Uncertainty avoidance (UA) represents the extent to which members of a culture feel uncomfortable in ambiguous situations that are considered novel or different from usual (Hofstede, 1984). High UA cultures tend to be more risk averse (Bontempo et al., 1997) than low UA cultures. Past research has already shown that consumers from risk-averse cultures generally associate more losses with the purchase of non-established brands and therefore tend to stay with well-established ones (Erdem et al., 2004). Moreover, the power of brand credibility, which is an advantage of manufacturers' brands over private labels, has been shown to be higher in high UA cultures (Erdem et al., 2006). This is consistent with market figures, which show that shoppers from Eastern cultures are more likely to prefer national or global brands as opposed to private labels (De Mooij and Hofstede, 2002). On this basis, the following is hypothesised:

H1d: There is a direct negative relationship between uncertainty avoidance and private label performance.

Direct Impact of Long-term Orientation. Long-term orientation (LTO) reflects the extent to which a society exhibits a pragmatic, future-oriented rather than a short-term perspective (Hofstede, 2001). It has been shown that individuals from high LTO cultures use consumption to achieve long-term goals rather than short-term benefits (Bearden et al., 2006). Therefore, consumers from LTO cultures will develop higher preferences for brands that have a higher quality image of products lasting longer (Petersen et al., 2015; Yalcinkaya, 2008). On the contrary, high LTO consumers are expected to develop lower preferences for brands that focus on immediate benefits such as price discounts, which are generally associated with the image of private labels. This rationale is consistent with past observations that show that consumers from high LTO countries are more attracted to national or global 
brands than private labels (De Mooij and Hofstede, 2002). The following is therefore hypothesised:

H1e: There is a direct negative relationship between long-term orientation and private label performance.

The Role of Retail Market Development

According to past research, the development of retail markets worldwide follows the progressive emergence of modern forms of retail outlets (as opposed to traditional ones) (Goldman et al., 2002; Steenkamp and Dekimpe, 1997)². Therefore, in this research, retail market development is defined as the size per capita of modern retail outlets: the bigger the sales represented by modern stores, the more this market is considered to be developed. Past research allows us to suggest that retail market development plays a mediating role in the relationship between culture and private label performance (Cuneo et al., 2015; Etgar and Rachman-Moore, 2011). On one hand, the cultural context in which a retail market is embedded influences its development toward modern outlets: for instance, although advanced Asian economies such as Hong Kong, South Korea and Taiwan have all the elements for modern retailers to acquire important market shares (long existence, acquisition of national retailers, high standard of living, etc.), their cumulative market share is well below 50\% (Goldman et al., 2002). Goldman and Hino (2005) suggest that retail market development is hindered in Asian cultures because small, traditional distribution retailers are considered a significant part of their social fabric. On the other hand, the hindrance of the development of

\footnotetext{
${ }^{2}$ The categorisation into modern or traditional outlets is well documented in the academic literature (Goldman et al., 1999). Traditional retail outlets are typically small, non-chain stores that are family run, employ marginal labour and use simple marketing operations. This category includes monocategory specialists (e.g. bakers, butchers and tobacconists), independent small grocers (owned by an individual entrepreneur) and very small and unorganised stores such as kiosks and markets. Modern retail outlets are multi-line operation retailers, often integrated in big chains and generally providing a wide range of different product categories. This category includes convenience stores (e.g. 7Elevens), discounters (e.g. Lidl and Netto) and supermarkets and hypermarkets (e.g. Carrefour and Tesco).
} 
modern retailers is in turn likely to limit the success of their private labels. Indeed, less modern retail markets display lower private label performance (Steenkamp and Dekimpe, 1997).

The following paragraphs provide theoretical justification for the direct impact of retail market development on private label performance and for the indirect impact of each cultural dimension on private label performance through the mediation of retail market development.

Direct Impact of Retail Market Development. Three main reasons lead us to hypothesise the existence of retail market development's influence on private label performance. First, large, modern retail chains are more likely to reach a sufficient critical size to own and market multi-line product categories under their name (Bell, 2003). Second, larger modern retailers can develop stronger negotiation power vis-à-vis national and international manufacturers, which is likely to favour private label development (Rubio and Yague, 2009). Finally, the competition between modern retailers positively affects private labels’ market share through more competitive prices and quality improvement (Corstjens and Lal, 2000). Thus, the following hypothesis is proposed:

H2: There is a direct positive relationship between retail market development and private label performance.

Indirect Impact of Power Distance. Past literature has shown that firms in high power distance (PD) cultures are characterised by more centralised decision processes (Hofstede, 2001). In high PD cultures, the installation/development of modern retailers is likely to be more dependent on a high level of autocratic decisions at the national level and therefore more likely to follow more traditional values coming from a centralised authority (Head and Sorensen, 2005). This could therefore contribute to a less favourable environment for the 
development of large, modern retail chains. This is consistent with the findings of Etgar and Rachman-Moore (2011), who posit that retailers originating from high PD countries are smaller, more specialised and more traditional than those from low PD countries. This, in turn, should have a negative impact on private label performance. Hence:

H3a: There is an indirect negative relationship between power distance and private label performance that is mediated by retail market development.

Indirect Impact of Individualism/Collectivism. Past research indicates that countries with low levels of individualism are less likely to accept international modern retail distribution channels (Straughan and Albers-Miller, 2001). Indeed, in collectivist societies, small, traditional retailers are viewed more favourably and considered more trustworthy, because they place higher importance on personal contact, which is a key element of the “social fabric” (Earley and Gibson, 1998). This is consistent with market observations which show that traditional retail stores in collectivistic countries have increased by one million over the last decade (Nielsen, 2014). The resulting lower development of the modern retail market is then likely to hinder the performance of private labels in a collectivist country. On the contrary, the development of modern retail chains most prominent and favoured in individualistic countries (e.g. the UK and US) is more likely to positively impact private label performance. Therefore:

H3b: There is an indirect positive relationship between individualism and private label performance that is mediated by retail market development.

Indirect Impact of Masculinity/Femininity. Among the few studies about masculinity and retail, Goldman and Hino (2005) show that in some countries where masculinity is particularly high, women are less often allowed to venture unaccompanied out of the "safe" 
radius around the home and should only go shopping in the neighbourhood (traditional) stores rather than in the more distant modern retailers. This leads to a higher patronage of small, traditional and independent stores rather than big supermarket chains. Other studies such as Marumaya and Trung (2007) show that the lower the role difference between males and females (i.e. the more women have access to jobs and the less they spend time on household chores), the more modern supermarkets develop to the detriment of traditional markets. It seems therefore that highly masculine cultures inhibit retail market development, which in turn negatively influences private label performance. Hence

H3c: There is an indirect negative relationship between masculinity and private label performance that is mediated by retail market development.

Indirect Impact of Uncertainty Avoidance. Previous research tends to suggest that high uncertainty avoidance cultures are less favourable to the development of modern retailers. First, it has been shown that that high uncertainty avoidance (i.e. low risk taking) is an environmental characteristic that inhibits entrepreneurship, innovation and market development (Sasaki, 1991). Moreover, studies show that the presence of big actors in markets are less accepted by high UA cultures, as they lead to situations where any individual firm’s actions would be too consequential for other firms (Achrol and Stern, 1988). Therefore, high UA contexts may limit the development of modern retailers, which in turn may hinder the performance of private labels. Therefore:

H3d: There is an indirect negative relationship between uncertainty avoidance and private label performance that is mediated by retail market development.

Indirect Impact of Long-term Orientation. Past research shows that cultures that are characterised by high levels of long-term orientation (LTO) give importance to tradition and 
therefore take longer to embed modern foreign businesses into their society (Rubera and Kirca, 2012). This suggests that the development of modern retailers is facilitated in shortterm oriented cultures compared to LTO cultures. This is consistent with the findings of other studies such as those by Panday et al. (2015) and Khare (2013), who specifically states that LTO is a major predictor of people's preference for small, traditional retail outlets over modern retailers. This should in turn hinder the performance of the private labels of these modern retailers. Therefore:

HЗe: There is an indirect negative relationship between long-term orientation and private label performance that is mediated by retail market development.

The Role of Socioeconomic Variables and Competitive Intensity

It is important to control for socioeconomic factors, as past studies have shown their critical impact on preference for private labels, even in culturally similar countries (Zielke and Komor, 2015). Based on past research, we identify three main socioeconomic factors to be used as key control variables in our model, namely GDP per capita, government expenditures and income inequality. First, GDP per capita is a macro-level indicator that provides an overall assessment of a nation's income and thus its ability to spend money on goods and services (Roth, 1995). It has been shown to be closely related to the development of national markets (Spencer and Gomez, 2004) and has been used as a control variable in numerous private label performance models (e.g. Steenkamp et al., 2010). Second, government expenditures on health, welfare, education and physical infrastructure have been shown to substantially impact retail markets, either through local spending that may indirectly increase the demand for goods and services provided by the retail firms or through programmes providing direct assistance to retail firms (Douglas and Craig, 2011). Third, income inequality is considered an important influencer of markets and consumption 
behaviours within a country (Talukdar et al., 2002). For instance, it has been shown that the relative proportion of spending on basic versus expensive items is very different according to income level (Wu, 1997), and high inequality in income could be a challenge for retailers, as this would reduce the importance of the middle class, which allocates a higher spending share to retail products (Wong and $\mathrm{Yu}, 2002$ ).

Finally, past research on private label performance recommends taking into account the intensity of the competition in the market (Steenkamp et al., 2010). It is indeed likely that private label performance may be hindered by the presence of big national or international manufacturer brands in the market, as private labels would have to compete with large and powerful actors. Figure 1 shows the conceptual framework that links cultural dimensions to retail market development and private label performance, using socioeconomic factors as control variables.

\section{--- INSERT FIGURE 1 ABOUT HERE ---}

\section{METHODOLOGY}

Dataset Building

Following numerous previous studies that have investigated the impact of culture at the country level (e.g. Deleersnyder et al., 2009; Yeniyurt and Townsend, 2003), we used secondary data representing country-level values of the studied variables to build our dataset. Two different data sources were used. First, information about private label performance, retail market development and socioeconomic indicators comes from the GMID Euromonitor Database (www.euromonitor.com), which provides detailed yearly statistics on macroeconomic indicators and market figures for numerous industries and countries. In this study, we use the values of these variables for the year 2010, and we chose to concentrate on the 
packaged food category, as it is particularly representative of product categories where private labels have emerged as fierce competitors of national brands (Lamey et al., 2012). Second, information about national culture dimensions was gathered from the Hofstede model database (Hofstede et al., 2010), which provides updated scores of the different cultural dimensions for a large number of countries. In total, our dataset includes the 65 countries that are common to these two sources, representing all areas of the world, including Western and Eastern Europe, the Middle East, Australasia and North, Central and South America (cf. Appendix 1 for a list of countries).

Measures and Computation of Variables

Main Variables in the Model

Private label performance was computed as the mean of the private label value market share in each type of retailer in a country weighted by the value market share of this retailer type in the country. Retail market development was represented by the cumulative sales per capita reached by modern retail outlets in a country (convenience stores, discounters, forecourt retailers, supermarkets and hypermarkets). It was considered per capita to compare countries with different population sizes. Moreover, it was expressed in US dollars using the Purchasing Power Parity Index (PPPI) method. Unlike the ordinary average exchange rate method, the PPPI conversion allows for a relevant comparison across countries by converting each domestic currency into US dollars by applying a specific factor representing the number of units of a country's currency required to buy the same amount of goods and services in the domestic market as one US dollar would buy in the United States. The use of the PPPI method therefore allows us to compare countries with different currencies and different levels of purchasing power (Yeniyurt and Townsend, 2003). The culture dimensions' scores for 
power distance, individualism, masculinity, uncertainty avoidance and long-term orientation reflect the absolute scores from Hofstede et al. (2010).

\section{Control Variables}

In line with previous calculations, GDP and government expenditure (in value) were considered per capita (divided by the number of inhabitants) and also expressed in US dollars (with PPPI) to enable the comparison of countries of different sizes, currencies and purchasing powers. To capture the level of income inequality in a country, we used the Gini index. The Gini index ranges from 0 to 1 , where 0 represents perfect equality of income repartition within the population, and 1 represents the highest possible inequality. Finally, competitive intensity was represented by the Herfindahl index, which was computed as the sum of the square of the market share of all the brands competing in the grocery product market. Table 2 recapitulates the operational definition of each variable in the model as well as the raw data source.

--- INSERT TABLE 2 ABOUT HERE ---

\section{ANALYSIS AND FINDINGS}

\section{Descriptive Statistics}

Table 3 provides the descriptive statistics for both the independent and dependent variables: means, standard deviations and correlation matrix. As expected, the level of private label performance and retail market development varied across countries.

Model Estimation 
We used AMOS 23 to perform structural equation modelling (SEM), employing a maximum likelihood estimation method. The use of SEM in the present study is justified by the following reasons. First, SEM is generally considered a very powerful tool for theory testing, as it allows for the simultaneous estimation of all the relationships of a conceptual model and the determination of the fit of these empirical relationships with the structure of the theoretical model (Iacobucci, 2010). Second, even if SEM often uses unobservable, latent variables measured with multiple items, past studies show that this method is also robust when, as in the present study, variables are measured by a single indicator, as long as information about the potential measurement error is included in the model (Steenkamp and Baumgartner, 2000). Third, even though earlier studies recommend a sample size larger than 200 (Kline, 2005), most recent works claim that this rule is too conservative (Iacobucci, 2010). A significant number of SEM studies use samples smaller than 100 (MacCallum and Austin, 2000), and Bagozzi and Yi (2012) show that satisfactory models have been obtained with samples of three respondents per estimated parameter, which is exceeded in the present study.

We adopted an incremental model building approach (Hair et al., 2010) by sequentially adding groups of variables into the analysis and testing whether the addition of these variables improved the model fit. This led us to sequentially test four different models. In the first model, we specified only a relationship between retail market development and private label performance (Model 1). In the second model, we incorporated the group of socioeconomic factors: GDP per capita, the Gini index and government expenditures (Model 2). In the third model, we specified the impact of the five cultural dimensions on retail market development (Model 3). In the fourth and final model, we added the direct impact of cultural dimensions on private label performance (Model 4). In each of the four models, retail market development and private label performance were modelled as endogenous variables, with 
error terms included for both variables as a part of the model. These error terms were assumed to be uncorrelated with other variables within the model. The five cultural dimensions are considered exogenous independent variables, and the three socioeconomic factors are considered covariates to control for possible confounds.

Table 4 reports the chi-square $\left(\chi^{2}\right)$ values and degrees of freedom (df) of each model as well as the chi-square difference $\left(\Delta \chi^{2}\right)$ and degree of freedom difference $(\Delta \mathrm{df})$ between successive models. Model fit is considered significantly better than that of another if the chisquare difference is greater than the value of the $10 \%$ significance threshold [ $\left.\chi_{.10}^{2}(\Delta d f)\right]$. The values displayed in Table 3 show that Model 2 provides a significant fit improvement compared to Model $1\left(\Delta \chi^{2}=80.05\right.$ higher than $\left.\chi^{2} .10(\Delta d f)=12.02\right)$, Model 3's fit is significantly better than that of Model $2\left(\Delta \chi^{2}=34.50\right.$ higher than $\left.\chi^{2} .10(\Delta \mathrm{df})=9.24\right)$ and finally Model 4's fit is significantly better than that of Model $3\left(\Delta \chi^{2}=9.37\right.$ higher than $\left.\chi^{2} .10(\Delta \mathrm{df})=9.24\right)$. Therefore, Model 4, which specifies all the links hypothesised in our conceptual framework, provides the best fit with the data. This shows that the inclusion of cultural dimensions in the model as well as their impact on retail market development and private label performance significantly improves the fit indices of the model and the explanation of the level of private label brands’ performance.

------- INSERT TABLE 4 ABOUT HERE ------------

Test of Hypotheses

Table 5 provides the values and significance levels of the different path coefficients tested in the four models. To examine the validity of our hypotheses, we use Model 4, which provides the best $\chi^{2}$. As shown in Table 4, this better fit is confirmed by other fit indices, as 
Model 4 also displays the highest CFI (.972) and TLI (.939) as well an appropriate RMSEA (.068) between .03 and .08 (Hair et al., 2010).

\section{--- INSERT TABLE 5 ABOUT HERE ---}

Regarding the direct relationship between culture and private label performance, the results show a direct positive impact of individualism on private label performance $(\gamma=.103$, $\mathrm{t}=2.071, \mathrm{p}<.05$ ), which confirms H1b. In addition, there is a significant positive direct relationship between long-term orientation and private label brands' performance $(\gamma=.085$, $\mathrm{t}=2.266, p<.05)$. This contradicts H1e, which theorises a negative relationship between the two. Finally, the results do not show a direct relationship between power distance, masculinity and uncertainty avoidance and private label performance. Hence, H1a, H1c and H1d are not supported.

In terms of the role of retail market development as a mediator between cultural dimensions and private label performance, the results show that retail market development has a significant impact on private label performance $(\gamma=5.497, \mathrm{t}=3.256, p<.01)$, which confirms H2. They also show that retail market development is significantly negatively impacted by power distance $(\gamma=-.011, \mathrm{t}=-3.416, p<.01)$ and masculinity $(\gamma=-.006, \mathrm{t}=$ 2.071, $p<.05)$ but significantly positively impacted by individualism $(\gamma=.013, \mathrm{t}=3.98$, $p<.01)$ and uncertainty avoidance $(\gamma=.004, \mathrm{t}=1.681, p<.10)$. However, the direct relationship between long-term orientation and retail market development is not significant.

To be able to conclude about our hypotheses regarding the indirect impact of culture on private label performance through the mediation of retail market development, a bootstrapping analysis was performed. The number of bootstrap samples was fixed to 2,000 and the confidence level of the biased corrected confidence interval was .95. The results, 
provided in Table 6, show a negative indirect impact of power distance $(\gamma=-.060, p<.01)$ and masculinity $(\gamma=-.033, p<.05)$ on private label performance mediated by retail market development, which confirms both H3a and H3c, respectively. Moreover, the results show that private label performance is indirectly and positively impacted by individualism $(\gamma=.070, p<.01)$, which confirms H3b. The results also show an indirect positive impact of uncertainty avoidance on private label performance $(\gamma=.023, p<.10)$, which disconfirms H3d. Finally, the results show that long-term orientation does not have an indirect impact on private label performance $(p=.495)$, which disconfirms HЗe.

\section{--- INSERT TABLE 6 ABOUT HERE ---}

\section{DISCUSSION}

This study examines how the five dimensions of the Hofstede model of culture influence private label performance. Two types of impact are considered: a direct impact that represents how consumers are influenced by their culture in their choice of brand and an indirect path that shows how culture favours or inhibits the development of modern retail chains, which in turn influences the performance of the private labels of these modern retail formats. We use a SEM incremental model building approach using packaged food industry data from 65 countries to test our model, and we control for important factors such as competitive intensity and macro-level socioeconomic factors. In summary, our results show 1) a positive direct impact of individualism and long-term orientation on private label performance, 2) a positive indirect impact of individualism and uncertainty avoidance on private label performance through the mediation of retail market development and 3) a negative indirect impact of power distance and masculinity on private label performance mediated by retail market development. 
The positive direct impact of individualism confirms our hypothesis and is consistent with past research showing that consumers from collectivist countries are more prone to reject private labels, as these labels are less helpful to fulfil their need of conveying a highstatus image (De Mooij and Hofstede, 2002; Lupton et al., 2010). The impact of long-term orientation had not been previously tested, but previous research led us to expect that consumers from long-term oriented cultures would prefer national brands more often associated with enduring quality and durability (Petersen et al., 2015; Yalcinkaya, 2008). Our results go against these expectations; this can be explained by the fact that consumers from long-term oriented consumers prefer saving money for the future rather than spending it in the present (Hofstede et al., 2010), which would orient their choice toward cheaper private label products over more expensive national brands. Finally, the absence of the impact of the three dimensions (power distance, masculinity and uncertainty avoidance) may be explained by a change in the image of private labels over the years: most modern retailers may now have developed a national presence and high brand awareness, and consumers may perceive less uncertainty and less concern for social status in products offered under private labels.

The limited direct impact of cultural dimensions on private label performance (only two dimensions out of five) may explain why so little work has been published on the topic. This is why the study of its indirect impact through the mediation of retail market development represents an important contribution of this paper. Our results show that culture influences the development of modern retail formats in a country, which in turn has an effect on private label performance, as modern retailers are more prone to develop their own labels. More specifically, confirming our hypotheses, our results show an indirect impact of three dimensions: a negative impact of power distance and masculinity and a positive impact of individualism. However, contrary to our hypothesis, our analysis reveals a positive indirect relationship between uncertainty avoidance and private label performance. This result may be 
explained by the fact that, as shown by Etgar and Rachman-Moore (2011), the higher the uncertainty avoidance level in a country, the more retail firms will be willing to diversify in order to distribute the risk across numerous product categories. This should lead to more generalist, modern-like types of retail formats. Finally, we do not find any support for the hypothesis on the indirect impact of long-term orientation on private label performance.

\section{MANAGERIAL IMPLICATIONS}

Our research provides useful insights for managers, particularly regarding international retailing decisions. We focus here on two critical decisions: market selection and private label adaptation.

Market Selection. Most of the time, international managers decide which new markets to penetrate by solely using information such as retail market size, competition and the population's disposable income (Sternquist, 2011). Our study shows that international retailers should also select the most promising markets based on their score on different cultural dimensions. High individualistic countries should be targeted in priority, as they offer a favourable environment for the development of modern retail formats and because individualism positively influences the potential success of private labels. Moreover, cultures displaying high levels of uncertainty avoidance and long-term orientation should also be strongly considered, as they positively serve modern retail format and private label performance, respectively. On the contrary, retailers should be aware that selecting countries with high levels of power distance and masculinity will lead to higher challenges, as these cultural dimensions tend to inhibit the development of a modern retail environment and consequently private labels.

Moreover, international retail managers operating within environments characterised by high collectivism, such as Asian markets, have to be aware that consumers will prefer to 
shop in local, small retail outlets than in large retailers (Goldman and Hino, 2005). To increase their development, and subsequently the performance of their private labels within these markets, retailers should increase store attractiveness for consumers from collectivist cultures, by serving as "social link builders” within the community, perhaps by opting for smaller specialist formats that are perceived to be closer to traditional retail formats (Etgar and Rachman-Moore, 2011). For instance, Wal-Mart in China decided to open much smaller stores than the usual size in the US (100,000 square feet versus 260,000 square feet) containing a much lower number of products.

Private Label Strategy Adaptation. Past research differentiates between global (standardised and globally centralised) versus multinational (decentralised and locally adaptive) retailers (Salmon and Tordjman, 1989). Our results give some indications to the latter type of retailers that are able to adapt their private label strategy to the local context of each country. Private labels range from cheap, mere copycats to more expensive premium brands that can compete in quality with well-known manufacturer brands (Sternquist, 2011). Our results give some indications in regard to how to position private labels on this continuum according to the country’s scores on cultural dimensions. Retailers operating in countries that rank highly on collectivism should develop premium private labels that match that can compete with leading national brands in terms of quality perception, and that consumers could potentially see as fulfilling status needs. This confirms the observations of Jin and Suh (2005), who argue that emphasising the low price of private label brands is not effective in convincing collectivist Korean shoppers. This may, for instance, partly explain the success of the strategy followed by retail giant Carrefour, which decided to build a more premium position in China than in Western countries for its private label "Reflets de France". On the contrary, international retailers marketing private label groceries in highly individualistic or long-term oriented cultures should continue to focus on characteristics such 
as cost-savings, convenience and availability, as individualistic consumers are less concerned with image and more with self-directed benefits (De Mooij and Hofstede, 2002; Lupton et al., 2010; Shannon and Mandhachitara, 2005).

\section{LIMITATIONS AND FUTURE RESEARCH}

Like any other study, ours is not free of limitations. First, our choice of the Hofstede model fits the country-level focus of our study; however, we acknowledge that this model has received some criticism. Hence, future studies could examine novel dimensions of culture based on alternative frameworks (such as the GLOBE project) or employ multiple cultural models. Second, this study uses secondary data. While this approach is often recommended for cross-country comparisons, it is also sometimes criticised for its potential limitations pertaining to accuracy. Future cross-country-level research could complement the Hofstede scores with primary data. For instance, adapting the Hofstede dimensions to the individual level (Yoo and Donthu, 2002) would allow for the study of individual-level considerations such as the impact of psychographics and perceptual variables. Third, some of the socioeconomic factors used as control variables in our model (such as GDP per capita) are correlated with the Hofstede cultural dimensions, which could cause some confounding effects. A VIF analysis showed that multicollinearity was not a problem in this study, but it would be interesting to find an alternative way of measuring covariates that are not correlated with cultural dimensions. Finally, this study empirically explored the impact of cultural dimensions on private label performance and retail market development. Future research should perhaps investigate this relationship by focusing on additional moderators, which may provide better and fuller insight into the role of all cultural dimensions on private label performance and retail market development. 


\section{References}

Achrol, R.S. and Stern, L.W. (1988), “Environmental determinants of decision-making uncertainty in marketing channels”, Journal of Marketing Research, Vol. 25 No. 1, pp. 36-50.

Ackerman, D. and Tellis, G. (2001), “Can culture affect prices? A cross-cultural study of shopping and retail prices”, Journal of Retailing, Vol. 77 No. 1, pp. 57-82.

Ailon, G. (2008), “Mirror, mirror on the wall: Culture's consequences in a value test of its own design”, Academy of Management Review, Vol. 33 No. 4, pp. 885-904.

Anchor, J.R. and Kourilova, T. (2009), “Consumer perceptions of own brands: international differences”, Journal of Consumer Marketing, Vol. 26 No. 6, pp. 437-449.

Bagozzi, R.P. and Yi, Y. (2012), "Specification, evaluation, and interpretation of structural equation models”, Journal of the Academy of Marketing Science, Vol. 40 No.1, pp. 834.

Bearden, W.O., Money, R.B. and Nevins, J.L. (2006), “A measure of long-term orientation: Development and validation”, Journal of the Academy of Marketing Science, Vol. 3 No. 3, pp. 456-467.

Bell, R. (2003), “Competition issues in European grocery retailing”, European Retail Digest, No. 39, pp. 27-37.

Bello, D.C. and Dahringer, L.D. (1985), “The influence of country and product on retailer operating practices: A cross national comparison”, International Marketing Review, Vol. 2 No. 2, pp. 42-52.

Bolton, L.E., Keh, H.T. and Alba, J.W. (2010), "How do price fairness perceptions differ across cultures”, Journal of Marketing Research, Vol. 47 No. 3, pp. 564-576.

Bontempo, R.N., Bottom, W.P. and Weber, E.U. (1997), “Cross-cultural differences in risk perception: A model-based approach”, Risk Analysis, Vol. 17 No. 4, pp. 479-488. 
Burt, S., Davies, K., McAuley, A. and Sparks, L. (2005), "Retail internationalisation: From formats to implants”, European Management Journal, Vol. 23 No. 2, pp. 195-202.

Cadogan, J. (2010), “Comparative, cross-cultural, and cross-national research: A comment on good and bad practice”, International Marketing Review, Vol. 27 No. 6, pp. 601-605.

Corstjens, M. and Lal, R. (2000), “Building store loyalty through store brands”, Journal of Marketing Research, Vol. 37 No. 3, pp. 281-291.

Cuneo, A., Milberg, S.J., Benavente, J.M. and Palacios-Fenech, J. (2015), “The growth of private label brands: A worldwide phenomenon?”, Journal of International Marketing, Vol. 23 No. 1, pp. 72-90.

Dawson, J. and Mukoyama, M. (2006), The international transfer of key success factors, In Dawson et al. (Eds) Strategic issues in international retailing, Routledge, New-York.

De Mooij, M. (2011), Consumer behaviour and culture: consequences for global marketing and advertising, $2^{\text {nd }}$ ed., Sage Publications.

De Mooij, M. (2013), Global marketing and advertising: understanding cultural paradoxes, Sage Publications.

De Mooij, M. and Hofstede, G. (2002), “Convergence and divergence in consumer behaviour: Implications for international retailing”, Journal of Retailing, Vol. 78 No. 1, pp. 61-69.

De Mooij, M. and Hofstede, G. (2010), “The Hofstede model applications to global branding and advertising and research”, International Journal of Advertising, Vol. 29 No. 1, pp. 85-110.

Deleersnyder, B., Dekimpe, M.G., Steenkamp, J-B.E.M. and Leeflang, P. (2009), “The role of national culture in advertising's sensitivity to business cycles: an investigation across continents”, Journal of Marketing Research, Vol. 46 No. 5, pp. 623-636. 
Dhar, S.K. and Hoch, S.J. (1997), "Why store brand penetration varies by retailer”, Marketing Science, Vol. 16 No. 3, pp. 208-227.

Doran, K. (2002), “Lessons learned in cross-cultural research of Chinese and North American consumers”, Journal of Business Research, Vol. 55 No. 10, pp. 823-829.

Douglas, S.P. and Craig, C.S. (2011), “The role of context in assessing international marketing opportunities”. International Marketing Review, Vol. 28 No. 2, pp. 150162.

Earley, P.C. and Gibson, C.B. (1998), “Taking stock in our progress on individualismcollectivism: 100 years of solidarity and community”, Journal of Management, Vol. 24 No. 3, pp. 265-304.

Eisend, M., Evanschitzky, H. and Gilliland, D.I. (2016), “The influence of organizational and national culture on new product performance”, Journal of Product Innovation Management, Vol. 33 No. 3, pp. 260-276.

Erdem, T., Swait, J. and Valenzuela, A. (2006), “Brands as signals: A cross-country validation study”, Journal of Marketing, Vol. 70 No. 1, pp. 34-49.

Erdem, T., Zhao, Y. and Valenzuela, A. (2004), “Performance of store brands: a crosscountry analysis of consumer store-brand preferences, perceptions, and risk”, Journal of Marketing Research, Vol. 41 No. 1, pp. 86-100.

Etgar, M. and Rachman-Moore, D. (2011), “The relationship between national cultural dimensions and retail format strategies”, Journal of Retailing and Consumer Services, Vol. 18 No. 5, pp. 397-404.

Goldman, A. and Hino, H. (2005), “Supermarkets vs. traditional retail stores: diagnosing the barriers to supermarkets' market share growth in an ethnic minority community”, Journal of Retailing and Consumer Services, Vol. 12 No. 4, pp. 273-284. 
Goldman, A., Krider, R. and Ramaswami, S. (1999), “The persistent competitive advantage of traditional food retailers in Asia: wet markets' continued dominance in Hong Kong”, Journal of Macromarketing, Vol. 19 No. 2, pp. 126-139.

Goldman, A., Ramaswami, S. and Krider, R.E. (2002), "Barriers to the advancement of modern food retail formats: theory and measurement”, Journal of Retailing, Vol. 78 No. 4, pp. 281-295.

Gomez, M. and Okazaki, S. (2009), “Estimating store brand shelf space: A new framework using neural networks and partial least squares”, International Journal of Market Research, Vol. 51 No. 2, pp. 243-266.

Hair, J.F., Wolfinbarger, M.F., Ortinau, D.J. and Bush, R.P. (2010), Essentials of marketing research, McGraw-Hill/Irwin.

Head, T.C. and Sorensen Jr, P.F. (2005), “Attracting foreign direct investments: The potential role of national culture”, Journal of American Academy of Business, Vol. 6 No. 1, pp.305-308.

Herstein, R., Tifferet, S., Abrantes, J. L., Lymperopoulos, C., Albayrak, T., and Caber, M. (2012), “The effect of personality traits on private brand consumer tendencies: a cross-cultural study of Mediterranean countries”, Cross Cultural Management: An International Journal, Vol. 19 No.2, pp. 196-214.

Hofstede, G. (1980), culture’s Consequences International Differences in Work-Related Values, $1^{\text {st }}$ ed., Sage Publications Ltd.

Hofstede, G. (1984), “Cultural dimensions in management and planning”, Asia Pacific Journal of Management, Vol. 1 No. 2, pp. 81-99.

Hofstede, G. (2001), Culture's consequences comparing values, behaviours, institutions, and organizations across nations, $2^{\text {nd }}$ ed., Sage Publications. 
Hofstede, G., Hofstede, G. J. and Minkov, M. (2010), Cultures and organizations: software of the mind (Rev. $3^{\text {rd }}$ ed.), McGraw-Hill, New York.

House, R.J., Hanges, P.J., Javidan, M., Dorfman, P. and Gupta, V. (2004), Culture, leadership, and organizations the GLOBE study of 62 societies, Sage Publications Inc.

Hyman, M.R., Kopf, D. and Lee, D. (2010), “Review of literature-future research suggestions: private label brands: benefits, success factors and future research”, Journal of Brand Management, Vol. 17 No. 5, pp. 368-389.

Iacobucci, D. (2010), “Structural equations modeling: Fit indices, sample size, and advanced topics”, Journal of Consumer Psychology, Vol. 20 No. 1, pp. 90-98.

Jamieson, L and Bass, F. (1989), “Adjusting stated intention measures to predict trial purchase of new products: a comparison of models and methods”, Journal of Marketing Research, Vol. 26 No 3, pp. 336-345.

Jin, B. and Suh, Y.G. (2005), "Integrating effect of consumer perception factors in predicting private brand purchase in a Korean discount store context”, Journal of Consumer Marketing, Vol. 22 No. 2, pp. 62-71.

Khare, A. (2013), “Culture, small retail stores, and Indian consumer preferences: A moderating role of demographics”, The International Review of Retail, Distribution and Consumer Research, Vol. 23 No. 1, pp. 87-109.

Kim, Y. and Zhang, Y. (2011), “Does power-distance influence consumers’ preference for luxury status brands?”, Advances in Consumer Research, Vol. 39, pp. 511-512.

Kirkman, B.L., Lowe, K.B. and Gibson, C. (2006), “A quarter century of culture's consequences: A review of empirical research incorporating Hofstede's cultural values framework”, Journal of International Business Studies, Vol. 37 No. 3, pp. 285-320.

Kline, R.B. (2005), Principles and Practice of Structural Equation Modeling, Second Edition, New York, The Guilford Press. 
Lalwani, A.K., Shavitt, S. and Johnson, T. (2006), "What is the relation between cultural orientation and socially desirable responding?”, Journal of Personality and Social Psychology, Vol. 90 No. 1, pp. 165-178.

Lamey, L., Deleersnyder, B., Steenkamp, J.B.E.M. and Dekimpe, M.G. (2012), “The effect of business-cycle fluctuations on private-label share: what has marketing conduct got to do with it?”, Journal of Marketing, Vol. 76 No. 1, pp. 1-19.

Lin, C-Y, Marshall, D. and Dawson, J. (2009), “Consumer attitudes towards a European retailers’ private brand food products: an integrated model of Taiwanese consumers”, Journal of Marketing Management, Vol. 25 No. 9-10, pp. 875-891.

Lupton, R.A., Rawlinson, D.R. and Braunstein, L.A. (2010), "Private label branding in China: what do US and Chinese students think?”, Journal of Consumer Marketing, Vol. 27 No. 2, pp. 104-113.

MacCallum, R.C. and Austin, J.T. (2000), “Applications of structural equation modeling in psychological research”, Annual Review of Psychology, Vol. 51 No. 1, pp. 201-226.

Marumaya, M and Trung L.V. (2007), "Supermarkets in Vietnam: opportunities and obstacles”, Asian Economic Journal, Vol. 21 No.1, pp. 19-46.

Nielsen (2014), “The state of private label around the world”, available at: http://www.nielsen.com/content/dam/nielsenglobal/kr/docs/globalreport/2014/Nielsen\%20Global\%20Private\%20Label\%20Report\%20November\%202 014.pdf (accessed 19 October 2015).

Panday, S., Khare, A. and Bhardwaj, P. (2015), “Antecedents to store loyalty: influence of culture, cosmopolitanism and price”, International Journal of Retail and Distribution Management, Vol. 43, No. 1, pp. 5-25. 
Petersen, J.A., Kushwaha, T. and Kumar, V. (2015), “Marketing communication strategies and consumer financial decision making: The role of national culture”, Journal of Marketing, Vol. 79 No. 1, pp. 44-63.

Robinson, C. (1996), “Asian culture: the marketing consequences”, Journal of the Market Research Society, Vol. 38 No. 1, pp. 55-62.

Roth, M.S. (1995), "Effects of global market conditions on brand image customization and brand performance”, Journal of Advertising, Vol. 24 No. 4, pp. 55-75.

Rubera, G. and Kirca, A.H. (2012), "Firm innovativeness and its performance outcomes: A meta-analytic review and theoretical integration”, Journal of Marketing, Vol. 76 No. 3, pp. 130-147.

Rubio, N. and Yagüe, M.J. (2009), “Alternative panel models to evaluate the store brand market share: evidence from the Spanish market”, European Journal of Marketing, Vol. 43 No. 1/2, pp. 110-138.

Salmon, W. and Tordjman, A. (1989), “The internationalization of retailing”, International Journal of Retailing, Vol. 4 No. 2, pp. 3-16.

Sasaki, T. (1991), “How the Japanese accelerated new car development”, Long Range Planning, Vol. 24 No. 1, pp. 15-25.

Schwartz, S.H. (1992), "Universal in the content and structure of values: Theoretical advances and empirical tests in 20 countries”, In M. Zanna (Ed.), Advances in experimental social psychology, Vol. 25 No. 1, 1-65. New York: Academic Press.

Sethuraman, R. and Gielens, K. (2014), “Determinants of store brand share”, Journal of Retailing, Vol. 90 No. 2, pp. 141-153.

Shannon, R. and Mandhachitara, R. (2005), “Private-label grocery shopping attitudes and behaviour: A cross-cultural study”, Journal of Brand Management, Vol. 12 No. 6, pp. 461-474. 
Singh, S. (2006), “Cultural differences in, and influences on, consumers' propensity to adopt innovations”, International Marketing Review, Vol. 23 No. 2, pp. 173-191.

Smith, P.B. (2006), "When elephants fight, the grass gets trampled: The GLOBE and Hofstede projects” Journal of International Business Studies, Vol. 37 No. 6, pp. 915921.

Soares, A.M., Farhangmehr, M. and Shoham, A. (2007), "Hofstede's dimensions of culture in international marketing studies”, Journal of Business Research, Vol. 60 No. 3, pp. 277-284.

Spencer, J.W. and Gómez, C. (2004), “The relationship among national institutional structures, economic factors, and domestic entrepreneurial activity: a multicountry study”, Journal of Business Research, Vol. 57 No. 10, pp. 1098-1107.

Steenkamp, J.B.E.M and Baumgartner, H. (2000), “On the use of structural equation models for marketing modelling”, International Journal of Research in Marketing, Vol. 17 No. 2, pp. 195-202.

Steenkamp, J.B.E.M. and Dekimpe, M.G. (1997), “The increasing power of store brands: building loyalty and market share”, Long Range Planning, Vol. 30 No. 6, pp. 917930.

Steenkamp, J.B.E.M. and Geyskens, I. (2014), “Manufacturer and retailer strategies to impact store brand share: Global integration, local adaptation, and worldwide learning”, Marketing Science, Vol. 33 No. 1, pp. 6-26.

Steenkamp, J-B.E.M., Van Heerde, H.J. and Geyskens, I. (2010), “What makes consumer willing to pay a price premium for national brands over private labels?”, Journal of Marketing Research, Vol. 47 No. 6, pp.1011-1024.

Sternquist, B (2011), International retailing theory and research, Haslett, MI:BSC Publisher. 
Straughan, R.D. and Albers-Miller, N.D. (2001), “An international investigation of cultural and demographic effects on domestic retail loyalty”, International Marketing Review, Vol. 18 No. 5, pp. 521-541.

Talukdar, D., Sudhir, K. and Ainslie, A. (2002), “Investigating new product diffusion across products and countries”, Marketing Science, Vol. 21 No.1, pp. 97-114.

Tifferet, S. and Herstein, R. (2010), “The effect of individualism on private brand perception: a cross-cultural investigation”, Journal of Consumer Marketing, Vol. 27 No. 4, pp. 313-323.

Triandis, H.C. (1989), “The self and social behavior in differing cultural contexts”, Psychological Review, Vol. 96 No. 3, pp. 506-520.

Triandis, H.C. (1994), Culture and Social behavior, McGraw-Hill, New York.

Wong, G.K-M. and Yu, L. (2002), “Income and social inequality in China: Impact on consumption snd shopping patterns”, International Journal of Social Economics, Vol. 29 No 5-6, pp. 370-384.

Wu, Y. (1997), "Wealth and spending patterns in China: Empirical evidence from household surveys”, International Journal of Social Economics, Vol. 24, pp 1007-1022.

Yalcinkaya, G. (2008), “A culture-based approach to understanding the adoption and diffusion of new products across countries”, International Marketing Review, Vol. 25 No. 2, pp. 202-214.

Yeniyurt, S. and Townsend, J.D. (2003), “Does culture explain acceptance of new products in a country? An empirical investigation”, International Marketing Review, Vol. 20 No. 4, pp. 377-396.

Yoo, B. and Donthu, N. (2002), “The effects of marketing education and individual cultural values on marketing ethics of students”, Journal of Marketing Education, Vol. 24 No. 2, pp. 92-103. 
Zielke, S. and Komor, M. (2015), “Cross-national differences in price-role orientation and their impact on retail markets”, Journal of the Academy of Marketing Science, Vol. 43 No. 2, pp. 159-180.

Zinkhan, G.M. and Prenshaw, P.J. (1994), “Good life images and brand name associations: Evidence from Asia, America, and Europe”, Advances in Consumer Research, Vol. 21, pp. 496-496. 
Table 1. Recapitulation of Cross-country Studies on Private Labels

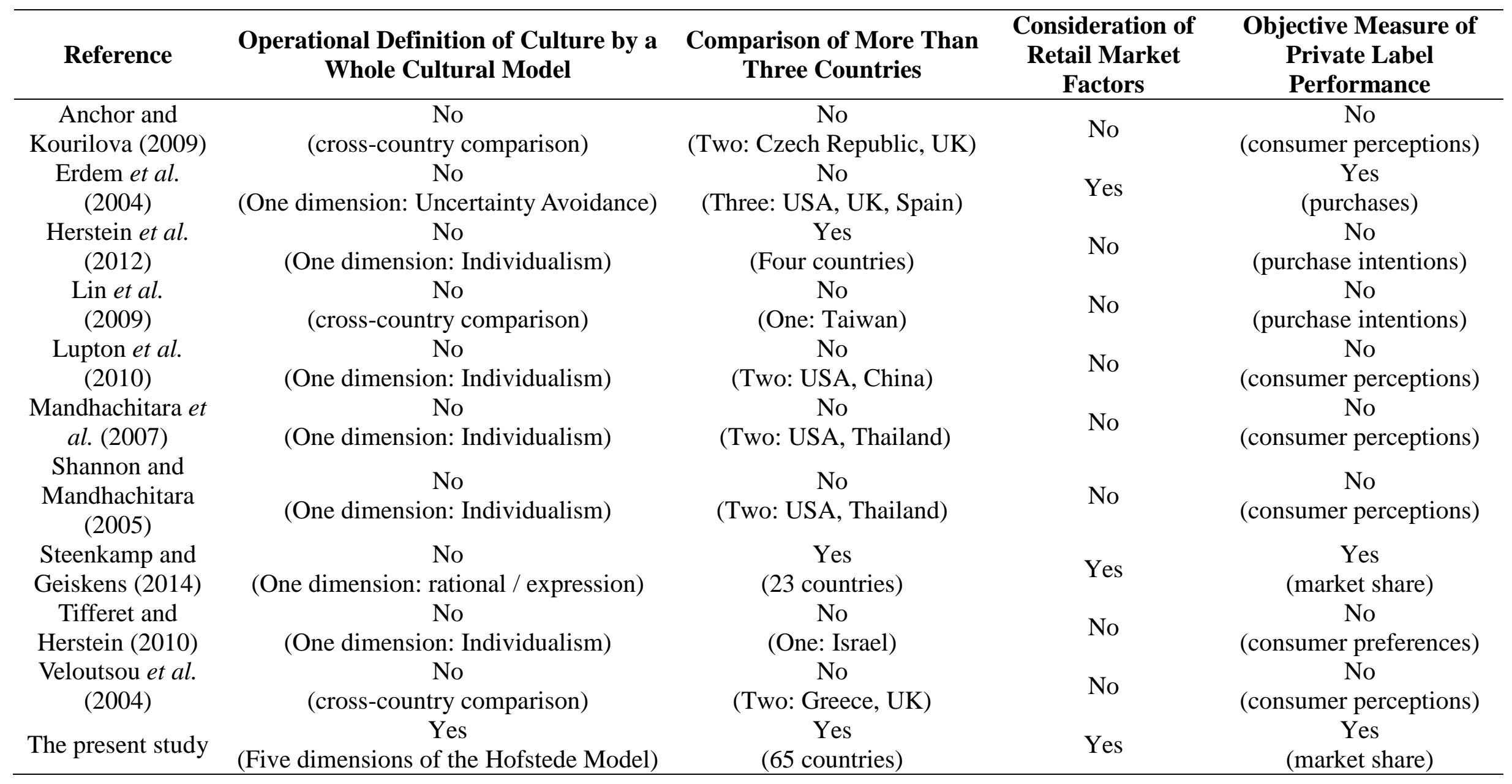


Table 2. Variable Definition and Data Source

Variable

Operational Definition

Raw Data

Source

\begin{tabular}{|c|c|c|}
\hline Private Label Performance & $\begin{array}{c}\text { Weighted average of private label market } \\
\text { share in each retailer, in value (\%) }\end{array}$ & Euromonitor \\
\hline Retail Market Development & $\begin{array}{l}\text { Sales per capita of modern retail outlets } \\
\text { corrected by the Purchase Power Parity } \\
\text { Index (PPPI, US\$) }\end{array}$ & Euromonitor \\
\hline Cultural Dimensions & $\begin{array}{l}\text { Absolute scores of each cultural } \\
\text { dimension }\end{array}$ & $\begin{array}{l}\text { Hofstede et al. } \\
\text { (2010) }\end{array}$ \\
\hline GDP per Capita & $\begin{array}{l}\text { GDP per capita corrected by the } \\
\text { PPPI (US\$) }\end{array}$ & Euromonitor \\
\hline Government Expenses & $\begin{array}{l}\text { Government expenses per capita } \\
\text { corrected by the PPPI (US\$) }\end{array}$ & Euromonitor \\
\hline Income Inequality & Value of the Gini index (from 0 to 1 ) & Euromonitor \\
\hline Competitive Intensity & $\begin{array}{l}\text { Herfindahl index: Sum of the square of } \\
\text { the market share of all brands on the } \\
\text { market }\end{array}$ & Euromonitor \\
\hline
\end{tabular}


Table 3. Measurement Information and Correlation Matrix

\begin{tabular}{|c|c|c|c|c|c|c|c|c|c|c|c|c|c|}
\hline & $\mathrm{M}$ & SD & 1 & 2 & 3 & 4 & 5 & 6 & 7 & 8 & 9 & 10 & 11 \\
\hline Private Label Performance & 9.37 & 10.16 & 1 & & & & & & & & & & \\
\hline Retail Market Development & 1.35 & 1.07 & $.75^{* *}$ & 1 & & & & & & & & & \\
\hline Power Distance & 58.11 & 23.15 & $-.53 * *$ & $-.70 * *$ & 1 & & & & & & & & \\
\hline Individualism & 43.78 & 23.82 & $.66^{* *}$ & $.73 * *$ & $-.61 * *$ & 1 & & & & & & & \\
\hline Masculinity & 49.77 & 19.32 & .07 & -.08 & -.01 & .12 & 1 & & & & & & \\
\hline Uncertainty Avoidance & 66.82 & 22.87 & -.07 & .06 & .16 & -.23 & -.02 & 1 & & & & & \\
\hline Long-term Orientation & 45.74 & 23.52 & $.32 *$ & $.28 *$ & -.13 & .14 & .11 & -.05 & 1 & & & & \\
\hline GDP & 23.87 & 15.11 & $.61^{* *}$ & $.77 * *$ & $-.56 * *$ & $.62 * *$ & -.04 & $-.26 *$ & $.33 * *$ & 1 & & & \\
\hline Government Expenditure & 712.34 & 2000.98 & -.23 & $-.26 *$ & .05 & $-.25 *$ & -.10 & -.06 & -.02 & -.21 & 1 & & \\
\hline Gini Index & 40.69 & 8.21 & $-.42 * *$ & $-.60 * *$ & $.42 * *$ & $-.45 * *$ & -.01 & -.15 & $-.49 * *$ & $-.44 * *$ & .13 & 1 & \\
\hline Competitive Intensity & .009 & .007 & $-.33 * *$ & -.19 & -.05 & -.21 & -.15 & -.18 & -.22 & -.17 & $.28 *$ & .23 & 1 \\
\hline
\end{tabular}


Table 4. Sequential Model Comparison

\begin{tabular}{cccccccc}
\hline Model & \multicolumn{1}{c}{$\chi^{2}$} & df & $\Delta \chi^{2}$ & $\Delta$ df & $\begin{array}{c}\text { Significance } \\
\text { threshold (10\%) }\end{array}$ & Fit \\
& & & & & $\chi_{.10}^{2}(\Delta d f)$ & improvement \\
\hline Model 1 & 156.42 & 42 & - & - & - & - \\
Model 2 versus Model 1 & 76.37 & 35 & 80.05 & 7 & 12.02 & Yes \\
Model 3 versus Model 2 & 41.87 & 30 & 34.50 & 5 & 9.24 & Yes \\
Model 4 versus Model 3 & 32.50 & 20 & 9.37 & 5 & 9.24 & Yes \\
\hline
\end{tabular}


Table 5. Incremental Model Building

\begin{tabular}{|c|c|c|c|c|}
\hline & Model 1 & Model 2 & Model 3 & Model 4 \\
\hline \multicolumn{5}{|l|}{ Impact of Culture on Private Label Performance } \\
\hline Power Distance $\rightarrow$ Private Label Perf (H1a) & - & - & - & -.029 \\
\hline Individualism $\rightarrow$ Private Label Perf (H1b) & - & - & - & $.103^{* *}$ \\
\hline Masculinity $\rightarrow$ Private Label Perf (H1c) & - & - & - & .026 \\
\hline Uncert Avoid $\rightarrow$ Private Label Perf (H1d) & - & - & - & .041 \\
\hline Long-term Or $\rightarrow$ Private Label Perf $(\mathbf{H 1 e})$ & - & - & - & $.085 * *$ \\
\hline \multicolumn{5}{|c|}{ Impact of Retail Market Development on Private Label Performance } \\
\hline Retail Market Dvt $\rightarrow$ Private Label Perf (H2) & $7.30 * * *$ & $6.74 * * *$ & $6.74 * * *$ & $5.49 * * *$ \\
\hline \multicolumn{5}{|l|}{ Impact of Culture on Retail Market Development } \\
\hline Power Distance $\rightarrow$ Retail Market Dvt (H3a) & - & - & $-.011 * * *$ & $-.011 * * *$ \\
\hline Individualism $\rightarrow$ Retail Market Dvt (H3b) & - & - & $.013^{* * *}$ & $.013^{* * *}$ \\
\hline Masculinity $\rightarrow$ Retail Market Dvt (H3c) & - & - & $-.006^{* *}$ & $-.006 * *$ \\
\hline Uncert Avoid $\rightarrow$ Retail Market Dvt (H3d) & - & - & $.004 *$ & $.004^{*}$ \\
\hline Long-term Or $\rightarrow$ Retail Market Dvt $(\mathbf{H} 3 \boldsymbol{e})$ & - & - & -.002 & -.002 \\
\hline \multicolumn{5}{|l|}{ Insertion of Control Variables } \\
\hline GDP $\rightarrow$ Retail Market Dvt & - & $.039 * * *$ & $.024 * * *$ & $.024 * * *$ \\
\hline Gini $\rightarrow$ Retail Market Dvt & - & $-.044 * * *$ & $-.027 * *$ & $-.027 * *$ \\
\hline Gov Expenditure $\rightarrow$ Retail Market Dvt & - & -.006 & -.005 & $-.005^{*}$ \\
\hline GDP $\rightarrow$ Private Label Perf & - & .071 & .071 & .011 \\
\hline Gini $\rightarrow$ Private Label Perf & - & .112 & .112 & $.275^{* *}$ \\
\hline Gov Expenditure $\rightarrow$ Private Label Perf & - & .015 & .015 & .017 \\
\hline Competitive Intens $\rightarrow$ Private Label Perf & - & $-.264 * *$ & $-.264^{* *}$ & $-.223 * *$ \\
\hline \multicolumn{5}{|l|}{ Model Fit Indices } \\
\hline Chi-Square $\left(\chi^{2}\right)$ & 156.419 & 76.365 & 41.872 & 32.497 \\
\hline Df & 42 & 35 & 30 & 25 \\
\hline R-Square $\left(\mathrm{R}^{2}\right)$ Retail Market Dvt & - & .658 & .805 & .805 \\
\hline R-Square $\left(\mathrm{R}^{2}\right)$ Private Label Perf & .550 & .560 & .565 & .628 \\
\hline CFI & .575 & .846 & .956 & .972 \\
\hline TLI & .444 & .725 & .919 & .939 \\
\hline RMSEA & .206 & .136 & .079 & .068 \\
\hline
\end{tabular}


Table 6. Mediating Effect of Retail Market Development

\begin{tabular}{|c|c|c|c|c|}
\hline & Estimate & Lower Bound* & $\begin{array}{c}\text { Upper } \\
\text { Bound* }\end{array}$ & Significance* \\
\hline Power Distance $(\mathbf{H} 3 \boldsymbol{a})$ & -.060 & -.150 & -.020 & .007 \\
\hline Individualism (H3b) & .070 & .026 & .159 & .008 \\
\hline Masculinity (H3c) & -.033 & -.092 & -.009 & .021 \\
\hline Uncertainty Avoidance (H3d) & .023 & .002 & .015 & .065 \\
\hline Long-term Orientation $(\mathbf{H} 3 \boldsymbol{e})$ & .008 & -.048 & .015 & .495 \\
\hline
\end{tabular}

* Biased Corrected (BC) 
Figure 1. Conceptual Framework

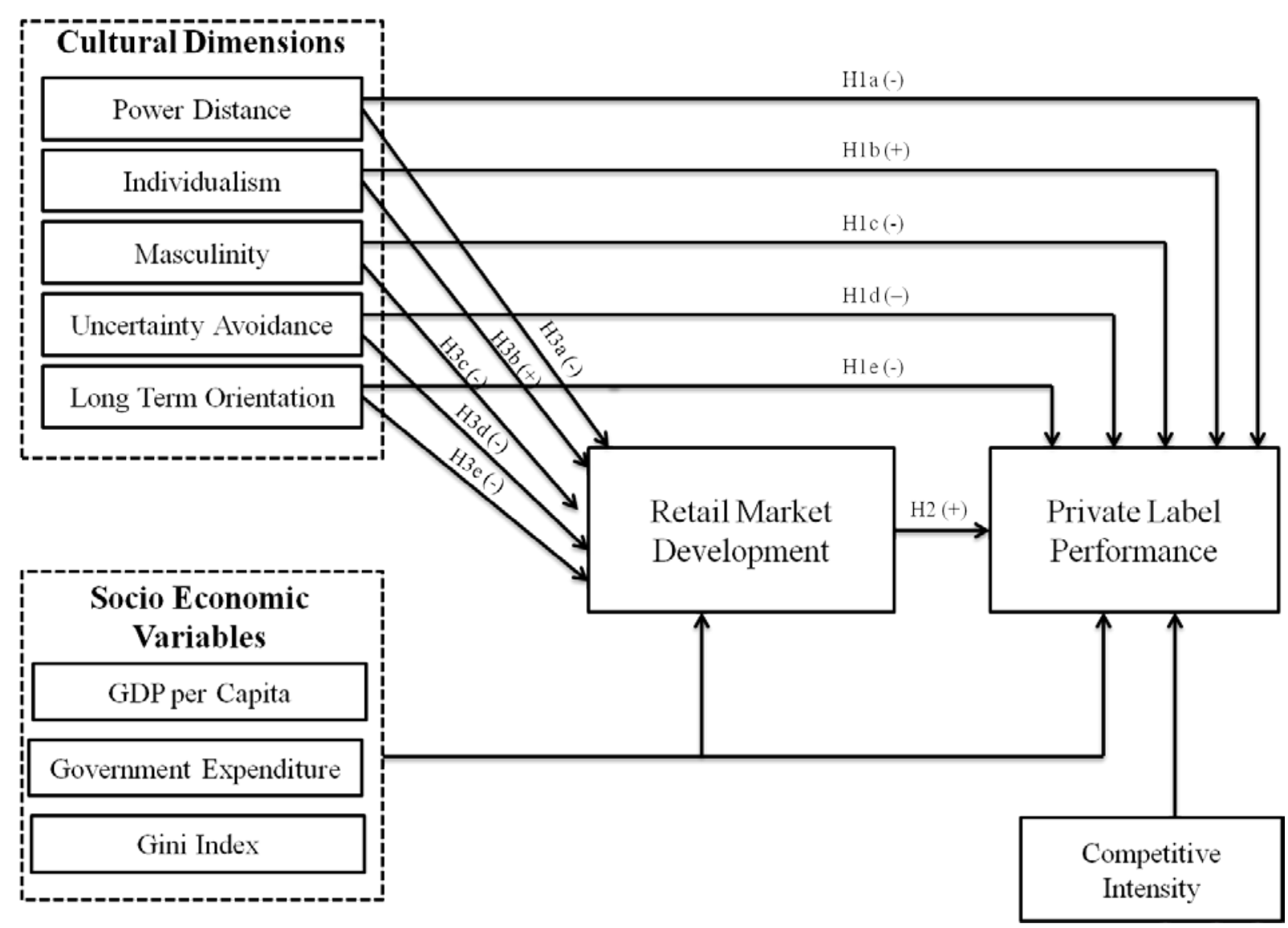


Appendix 1: Countries Included in the Analysis

\begin{tabular}{|c|c|c|c|c|c|c|}
\hline Asia Pacific & Australia & $\begin{array}{l}\text { Eastern } \\
\text { Europe }\end{array}$ & $\begin{array}{l}\text { Western } \\
\text { Europe }\end{array}$ & $\begin{array}{l}\text { North } \\
\text { America }\end{array}$ & $\begin{array}{l}\text { Latin } \\
\text { America }\end{array}$ & $\begin{array}{l}\text { Middle East } \\
\text { \& Africa }\end{array}$ \\
\hline $\begin{array}{l}\text { China } \\
\text { Hong Kong } \\
\text { India } \\
\text { Indonesia } \\
\text { Japan } \\
\text { Malaysia } \\
\text { Pakistan } \\
\text { Philippines } \\
\text { Singapore } \\
\text { South Korea } \\
\text { Taiwan } \\
\text { Thailand } \\
\text { Veitnam }\end{array}$ & $\begin{array}{l}\text { Australia } \\
\text { NewZealand }\end{array}$ & $\begin{array}{l}\text { Bulgaria } \\
\text { Croatia } \\
\text { Czech- } \\
\text { Republic } \\
\text { Estonia } \\
\text { Hungary } \\
\text { Poland } \\
\text { Romania } \\
\text { Russia } \\
\text { Serbia } \\
\text { Slovakia } \\
\text { Slovenia }\end{array}$ & $\begin{array}{l}\text { Austria } \\
\text { Belgium } \\
\text { Denmark } \\
\text { Finland } \\
\text { France } \\
\text { Germany } \\
\text { Greece } \\
\text { Ireland } \\
\text { Italy } \\
\text { Netherlands } \\
\text { Norway } \\
\text { Portugal } \\
\text { Spain } \\
\text { Sweden } \\
\text { Switzerland } \\
\text { Turkey } \\
\text { United Kingdom }\end{array}$ & $\begin{array}{l}\text { Canada } \\
\text { United } \\
\text { States }\end{array}$ & $\begin{array}{l}\text { Argentina } \\
\text { Brazil } \\
\text { Colombia } \\
\text { Chile } \\
\text { Costa Rica } \\
\text { Ecuador } \\
\text { Guatemala } \\
\text { Mexico } \\
\text { Peru } \\
\text { Uruguay } \\
\text { Venezula }\end{array}$ & $\begin{array}{l}\text { Egypt } \\
\text { Iran } \\
\text { Israel } \\
\text { Kenya } \\
\text { Morocco } \\
\text { Nigeria } \\
\text { Saudi Arabia } \\
\text { South Africa } \\
\text { United Arab } \\
\text { Emirates }\end{array}$ \\
\hline 13 & 2 & 11 & 17 & 2 & 11 & 9 \\
\hline
\end{tabular}

Total number of countries $=65$ 